\title{
Organic remains of tentaculitids: New evidence from Upper Devonian of Poland
}

Paweł Filipiak and Agata Jarzynka

Acta Palaeontologica Polonica 54 (1), 2009: 111-116 doi:http://dx.doi.org/10.4202/app.2009.0111

Organic remains of tentaculitids have been recovered during palynological research on archival samples from the

Dobrzyca 2 borehole (Western Pomerania). Until now tentaculitids are widely known from their abundant mineralised

shells. As organic remains, on the other hand, they have only been known since 2004. The present discovery is currently the second one of this kind found in Upper Devonian strata. The shape and morphology of some recognized tentaculitid organic remains are similar to embryonic and juvenile forms of dacryoconarids belonging to orders Nowakiida and Stylionida. Based on palynomorphs, the age of the two samples investigated has been established as Frasnian, RB and RD local miospore zones.

Key words: Tentaculita, Dacryoconarida, organic remains, Frasnian, Devonian, Western Pomerania, Poland

Paweł Filipiak [filipiak@us.edu.pl], Wydział Nauk o Ziemi, Uniwersytet Śląski, ul. Będzińska 60, PL-41-200 Sosnowiec, Poland; Agata Jarzynka [a.jarzynka@botany.pl], Instytut Botaniki im. Władysława Szafera, PAN, ul. Lubicz 46, PL-31-512 Kraków, Poland.

This is an open-access article distributed under the terms of the Creative Commons Attribution License (for details please see creativecommons.org), which permits unrestricted use, distribution, and reproduction in any medium, provided the original author and source are credited. 